\title{
Morphological Characterization of Four Leguminous Crops Cultivated in Two Agro Ecological Zone: Western and Guinean Savannah Highlands of Cameroon
}

\author{
Momo Wobeng Nelly Blondelle, \\ Department of Biological Sciences, Laboratory of Biodiversity and \\ Sustainable Development, University of Ngaoundere, Cameroon \\ Megueni Clautilde, \\ Head of Department of Biological Sciences, \\ University of Ngaoundere Cameroon \\ Mandou Mouncharou Marie Solange, \\ Department of Crop Science, FASA, University of Dschang, Cameroon

\section{Madou Chantal,} \\ Department of Biological Sciences, University of Ngaoundere, Cameroon. \\ Institute of Agricultural Research for Development (IRAD), \\ Garoua, Cameroon \\ Mapongmetsem Pierre Marie, \\ Head of Laboratory of Biodiversity and Sustainable Development, \\ University of Ngaoundere, Cameroon
}

Doi: 10.19044/esj.2019.v15n9p389 URL:http://dx.doi.org/10.19044/esj.2019.v15n9p389

\begin{abstract}
In 2014, quarter (1/4) of Africa populations were estimated to be suffering from hunger. In Cameroon, the demand for food is increasing while productivity was decreasing subsequently the food insufficiency. To solve this problem, leguminous crops were valorized in Cameroon. They represent a major source of protein especially among the poorest population, and are rich in essential amino acids such as lysine, supplementing thus the nutritional value of cereal and tuber diets. Nevertheless, their production faced the problem of soil degradation and loss of soil fertility. The main objective of this work was to characterize leguminous crops cultivated in two agro ecological zones of Cameroon. Investigations based on farmer's knowledge on leguminous crops cultivation were done in Western highlands and High Guinean savannah zones of Cameroon. During this survey, leguminous crops were collected for qualitative and quantitative analysis. Farmers which were mostly women have at least 10 years of experience on these leguminous crops
\end{abstract}


cultivation. They kept their seed for next cultivation season and did not use fertilizers in their field. Based on color of seeds, nine, seven, six and four ecotypes of representing beans, peanuts, Bambara groundnuts and soybeans respectively were found from study sites. Quantitative analysis of these ecotypes presents the diversity of beans, peanuts and soybeans $(p=0.00)$ according to their biometric parameters. Except the weight of Bambara groundnuts which were different $(\mathrm{p}=0.00)$ their size was similar among ecotypes.

Keywords: Diversity, ecotypes, leguminous crops

\section{Introduction}

In 2014, 805 million of global population were reported to be suffering from hunger and malnutrition (BMEL, 2015) with the quarter of this population from Africa (AGRIDAPE, 2016). In Cameroon, agriculture is the lifeblood of people, with about $70 \%$ of the labor force employed in this sector (DSCN, 2002; Molua, 2008). It represents an important factor for Cameroonian economy (Binam et al., 2004) and is amongst the main occupation of more than $70 \%$ of Cameroonian (Abia et al., 2016). It accounted for as much as $30 \%$ of the gross domestic product (GDP), and over $40 \%$ of total foreign exchange earnings (DSCN, 2002). The demand for food in the country is increasing due to rising incomes and agriculture needs to change to meet that demand (Dobermann and Nelson, 2013). But, the decline in soil fertility and erosion hazards lower the crop productivity in spite of the growing demographic and urbanization (Jayne et al., 2013; Meena et al., 2014). The availability of foodstuffs was improved considerably as far as leguminous crops, vegetal oil and tuber were concerned with cover rate of the needs for approximately $100 \%$ (IRAD, 2008). Following the principal goal of Objective of the Millennium for the Development (OMD) in Cameroon which is to eliminate extreme poverty and hunger (INS, 2015), utilization of leguminous crops such as peanuts, beans, soybeans and Bambara groundnuts need to be valorized.

Leguminous crops are growing all over the world but the greatest varieties grow in the tropical and sub-tropical regions (Ibeawuchi, 2007). They represent an important component of agricultural food crops consumed in developing countries, especially in Sub-Saharan African (SSA) countries (Akibode, 2011). They have been cropped by humans for centuries and were commonly included in cropping systems to provide fodder for animals and to enhance yields of subsequent grain crops (Sinclair and Vadez, 2012). Leguminous crops are largely cultivated and consumed in Cameroon (Kouebou et al., 2013) because of their low cost compared to cereals and their food supply in vegetal protein (IRAD, 2013). They are rich in essential amino 
acids such as lysine and constitute a major source of protein especially among the poorest population (Graham and Vance, 2003). Also the productivity of non-legume crops are enhanced by the inclusion of a legume in the cropping system (Maingi et al., 2001). Indeed, leguminous crops have the capability to fertilize the soil by fixing atmospheric nitrogen in the soil and allow the solubilization of phosphate ions to make these nutrients available to plants (Bossuet and Vadez, 2013; FAO, 2016). They represents the most relevant tool for cultural crops because of their exceptional diversity manifested in variety of vegetable forms that adapted to a wide range of ecological conditions (Morel et al., 2012). However, Cameroon is facing severe problems of low agricultural and leguminous crops production, linked to the decreasing of available land for agriculture. This consequently leads to increase the influence of different anthropogenic factors that can affect the diversity of various valuable legumes, (Madzivhandila et al., 2016). However, it is necessary to characterize leguminous crops for future breeding works. The present work uses farmer's knowledge and experiences on peanuts, beans, soybeans and Bambara groundnuts cultivation to assess their characteristics in Western and Guinean Savannah highlands zones of Cameroon.

\section{Material and methods \\ Study sites}

The study was conducted in two agro ecological zones of Cameroon (Guinean savannah Highlands: $5^{\circ} 42^{\prime \prime}$ to $8^{\circ} 36^{\prime \prime} \mathrm{N}$ and $11^{\circ} 24^{\prime \prime}$ to $14^{\circ} 36 \mathrm{E}$; Western highlands: $4^{\circ} 54^{\prime \prime}$ to $6^{\circ} 36^{\prime \prime} \mathrm{N}$ and $9^{\circ} 18^{\prime \prime}$ to $11^{\circ} 24^{\prime \prime E}$ ) (MINADER, 2010; MINRESI, 2007). These zones correspond to West, Northwest (Western highlands) and Adamawa (Guinean Savannah Highlands) regions of Cameroon. They were chosen because of their similarities in terms of their climate manifestation (tropical climate with two seasons: rainy and dry seasons) and their vegetation (trees savannah) (Molua and Lambi, 2015). The average temperature of these two zones are from 20 to $26^{\circ} \mathrm{C}$ for Guinean savannah and Western highlands respectively (MINADER, 2010; MINRESI, 2007). Within each region, annual statistics for production of leguminous crops were taken from regional delegation of the Ministry of Agriculture and Rural Development (MINADER). These statistics guided the selection of two divisions per region as study sub-sites where the leguminous crops were highly cultivated. From Western highlands, Menoua, Mifi, Mezam and Menchum were chosen while from High Guinean Savannah, Vina and Faro et Deo were chosen. 


\section{Investigation and leguminous crops sampling}

During survey in these sites, an investigation sheet was used to record knowledge of farmers on leguminous crops cultivation. From the study sites, 155 farmers were interviewed following the split plot experimental design with 5 locations as repetitions, 4 leguminous crops as principal factor, 3 regions as secondary factor and 2 divisions as tertiary factors. Information on the quantity of leguminous crops produced by years, the origin of seed cultivated (to know whether farmers kept their own seed from the previous harvest crops or they got it from the market), their years of experiences (it is based on the number of years of experience of farmers on growing target leguminous crops), the variety they used to cultivate and leguminous crops sample were collected directly from farmers.

\section{Characterization of leguminous crops}

Qualitative and quantitative analysis were carried out on the leguminous crops. Qualitative analysis consisted on recording morphological parameter like color of seed Touré et al. (2013); the hylium position, hylium color and the form of the seed. These parameters allow to group leguminous crops into ecotypes according to the color of seed. Quantitative analysis consisted on measuring parameters like the length of big size of seed (LBA) and length of small axis of seed (LSA) with an electronic digital caliper stainless hardened. The weight of 50 seeds of each ecotype was measured by using an accurate scale (PRL-4200 FF) and the ratio LBA/LSA was calculated.

\section{Statistical analysis}

Basic information obtained during investigation was analyzed as a descriptive statistic to give the proportion of each parameter recorded. ANOVA analysis of numeric data obtained with quantitative parameters of leguminous crops ecotypes was performed to determine statistical differences of these parameters among each ecotype with STATISTICA 7. The principal component analysis (PCA) was done with Past3_16 software to gather leguminous crops biometric parameters according to their similarities and differences. Through these values, the difference between each ecotype of each leguminous was established.

\section{Results \\ Socio-economic characteristics of farmers \\ Gender of farmers}

The gender of farmers interviewed is recorded in table 1 . Most of the farmers who cultivated beans, peanuts and Bambara groundnuts were women with percentage distribution of $56.52 \%, 70.45 \%$ and $90.90 \%$ respectively while soybeans cultivation was mainly done by men (57.57\%). 
Table 1: Gender of farmers (\%) interviewed during investigation

\begin{tabular}{lcccccccc}
\hline Localities & \multicolumn{3}{c}{ Beans } & \multicolumn{3}{c}{ Peanuts } & \multicolumn{3}{c}{ Bambara groundnuts } & \multicolumn{2}{c}{ Soybeans } \\
\cline { 2 - 9 } Menoua & $\mathbf{M}$ & $\mathbf{F}$ & $\mathbf{M}$ & $\mathbf{F}$ & $\mathbf{M}$ & $\mathbf{F}$ & $\mathbf{M}$ & $\mathbf{F}$ \\
Mifi & 20.0 & 19.23 & 15.38 & 16.12 & 0.00 & 16.66 & 5.26 & 0.00 \\
Mezam & 15.00 & 19.23 & 23.07 & 12.90 & 33.33 & 3.33 & 21.05 & 21.42 \\
Menchum & 0.00 & 30.76 & 0.00 & 22.58 & 33.33 & 13.33 & 5.26 & 35.71 \\
Vina & 10.00 & 23.07 & 7.69 & 19.35 & 0.00 & 26.66 & 15.78 & 21.42 \\
Faro et Déo & 30.00 & 3.84 & 30.76 & 12.90 & 0.00 & 20.00 & 26.31 & 0.00 \\
TOTAL & 25.00 & 3.84 & 23.07 & 16.12 & 33.33 & 20.00 & 26.31 & 21.42 \\
\hline
\end{tabular}

M: Male; F: Female

\section{Professional experience of farmers}

Experience of farmers was based on their number of years of cultivating the target leguminous crops (Table 2). Indeed, this parameter helps to know how long investigated farmers used to cultivate target crops. Our results showed that farmers who mostly cultivated beans have from 10 up to 20 years of experience $(47.82 \%)$. Besides, those who cultivated peanuts and Bambara groundnuts have at least 20 years of farming experience representing $47.72 \%$ and $42.42 \%$ population proportion respectively. So, from the study sites, farmers were really experienced in peanuts, beans and Bambara groundnuts cultivation. But, most of the farmers are not well experienced in soybeans cultivation. For this crop, we recorded an experience of 0 to 5 years representing $48.48 \%$ 
Table 2: Farmers experiences $(\%)$ in leguminous crops cultivation according to sampling sites

\begin{tabular}{|c|c|c|c|c|c|c|c|c|c|c|c|c|c|c|c|c|}
\hline \multirow[t]{2}{*}{ Localities } & \multicolumn{4}{|c|}{ Beans } & \multicolumn{4}{|c|}{ Peanuts } & \multicolumn{4}{|c|}{ Bambara groundnuts } & \multicolumn{4}{|c|}{ Soybeans } \\
\hline & $\bar{A}$ & $\mathbf{B}$ & $\mathbf{C}$ & $\mathbf{D}$ & $\mathbf{A}$ & $\mathbf{B}$ & $\mathbf{C}$ & D & $\bar{A}$ & $\mathbf{B}$ & $\mathrm{C}$ & D & $\bar{A}$ & $\mathbf{B}$ & $\mathbf{C}$ & D \\
\hline Menoua & 25 & 0.0 & 22.7 & 22.2 & 28.5 & 0.0 & 33.3 & 9.52 & 33.3 & 0.0 & 0.0 & 14.2 & 6.25 & 0.0 & 0.0 & 0.0 \\
\hline Mifi & 12.5 & 14.2 & 13.6 & 33.3 & 14.2 & 42.8 & 0.0 & 14.2 & 0.0 & 0.0 & 14.2 & 7.14 & 12.5 & 25.0 & 40.0 & 25.0 \\
\hline Mezam & 0.0 & 14.2 & 22.7 & 22.2 & 0.0 & 0.0 & 22.2 & 23.8 & 0.0 & 33.3 & 28.5 & 14.2 & 12.5 & 25.0 & 0.0 & 50.0 \\
\hline Menchum & 25 & 14.2 & 13.6 & 22.2 & 28.5 & 14.2 & 11.1 & 14.2 & 11.1 & 33.3 & 0.0 & 85.7 & 25 & 12.5 & 20.0 & 0.0 \\
\hline Vina & 25 & 14.2 & 18.1 & 0.0 & 0.0 & 42.8 & 22.2 & 14.2 & 0.0 & 33.3 & 42.8 & 14.2 & 18.7 & 12.5 & 0.0 & 25.0 \\
\hline $\begin{array}{l}\text { Faro et } \\
\text { Déo }\end{array}$ & 12.5 & 42.8 & 9.09 & 0.0 & 28.5 & 0.0 & 11.1 & 23.8 & 55.5 & 0.0 & 14.2 & 7.14 & 25 & 25.0 & 40.0 & 0.0 \\
\hline TOTAL & 17.3 & 15.2 & 47.8 & 19.5 & 15.9 & 15.9 & 20.4 & 47.7 & 27.2 & 9.09 & 21.2 & 42.4 & 48.4 & 24.2 & 15.1 & 12.1 \\
\hline
\end{tabular}

\section{Origin of seeds cultivated by farmers}

This parameter helps to know if farmers keep their own seed from the previous harvest crops or they get it from the market. Table 3 presents the proportion of seeds cultivated by the farmers according to study sites. Most of the farmer's kept beans $(89.13 \%)$, peanuts $(86.36 \%)$, soybeans $(78.78 \%)$ and Bambara groundnuts $(63.63 \%)$ seeds from their previous harvest for the next culture.

Table 3: Origin of seeds $(\%)$ cultivated by farmer

\begin{tabular}{|c|c|c|c|c|c|c|c|c|c|}
\hline \multirow[t]{2}{*}{ Localities } & \multicolumn{2}{|c|}{ Beans } & \multicolumn{2}{|c|}{ Peanuts } & \multicolumn{2}{|c|}{ Bambara groundnuts } & \multicolumn{3}{|c|}{ Soybeans } \\
\hline & PK & MA & PK & MA & PK & MA & PK & MA & OO \\
\hline Menoua & 17.07 & 40.00 & 13.15 & 33.33 & 9.52 & 25.00 & 3.84 & 0.00 & 0.00 \\
\hline Mifi & 19.51 & 0.00 & 15.78 & 16.16 & 9.52 & 0.00 & 19.23 & 0.00 & 100 \\
\hline Mezam & 19.51 & 0.00 & 15.78 & 16.66 & 14.28 & 16.66 & 19.23 & 20.00 & 0.00 \\
\hline Menchum & 17.07 & 20.00 & 13.15 & 33.33 & 38.09 & 0.00 & 15.38 & 40.00 & 0.00 \\
\hline Vina & 14.63 & 20.00 & 21.05 & 0.00 & 23.80 & 8.33 & 19.23 & 0.00 & 0.00 \\
\hline Faro et Déo & 12.19 & 20.00 & 21.05 & 0.00 & 4.76 & 50.00 & 23.07 & 40.00 & 0.00 \\
\hline TOTAL & 89.13 & 10.86 & 86.36 & 13.63 & 63.63 & 36.36 & 78.78 & 15.15 & 6.06 \\
\hline
\end{tabular}

PK: personal keeping; MA: market; OO: others origin 


\section{Fertilizers used by farmers}

With the aim of improving their crop yield and improving the fertility status of the soil, some farmers often use either chemical (NPK 20-10-10, 615-20, 12-6-20, urea) or organic (manure, compost) fertilizers while others allow their crops growing naturally without application of any amendment. Table 4 indicated that $47.82 \%, 90.90 \%, 93.93 \%$ and $75.75 \%$ of farmers were not using fertilizers for beans, peanuts, Bambara groundnuts and soybeans cultivation respectively.

Table 4: Fertilizers used by farmers (\%) in study sites

\begin{tabular}{lccccccccccccc}
\hline Localities & \multicolumn{3}{c}{ Beans } & \multicolumn{4}{c}{ Peanuts } & \multicolumn{4}{c}{$\begin{array}{c}\text { Bambara } \\
\text { groundnuts }\end{array}$} \\
\cline { 2 - 14 } & & $\mathbf{C}$ & $\mathbf{O}$ & $\mathbf{N}$ & $\mathbf{C}$ & $\mathbf{O}$ & $\mathbf{N}$ & $\mathbf{C}$ & $\mathbf{O}$ & $\mathbf{N}$ & $\mathbf{C}$ & $\mathbf{O}$ & $\mathbf{N}$ \\
Menoua & 18.75 & 25.00 & 18.18 & 0.00 & 33.33 & 15.00 & 100 & 0.00 & 12.90 & 0.00 & 33.33 & 0.00 \\
Mifi & 25.00 & 25.00 & 9.09 & 100 & 66.66 & 10.00 & 0.00 & 0.00 & 3.22 & 0.00 & 0.00 & 28.00 \\
Mezam & 6.25 & 37.50 & 18.18 & 0.00 & 0.00 & 17.50 & 0.00 & 0.00 & 16.12 & 0.00 & 33.33 & 20.00 \\
Menchum & 25.00 & 6.25 & 13.63 & 0.00 & 0.00 & 17.50 & 0.00 & 0.00 & 25.80 & 20.00 & 33.33 & 16.00 \\
Vina & 25.00 & 0.00 & 13.63 & 0.00 & 0.00 & 20.00 & 0.00 & 0.00 & 19.35 & 80.00 & 0.00 & 4.00 \\
Faro et & 0.00 & 0.00 & 27.27 & 0.00 & 0.00 & 20.00 & 0.00 & 0.00 & 22.58 & 0.00 & 0.00 & 32.00 \\
Déo & & & & & & & & & & & & \\
TOTAL & $\mathbf{3 4 . 7 8}$ & $\mathbf{1 7 . 3 9}$ & $\mathbf{4 7 . 8 2}$ & $\mathbf{2 . 2 7}$ & $\mathbf{6 . 8 1}$ & $\mathbf{9 0 . 9 0}$ & $\mathbf{3 . 0 3}$ & $\mathbf{3 . 0 3}$ & $\mathbf{9 3 . 9 3}$ & $\mathbf{1 5 . 1 5}$ & $\mathbf{9 . 0 9}$ & $\mathbf{7 5 . 7 5}$ \\
\hline
\end{tabular}

C: Chemical; O: Organic; N: No fertilizers

\section{Qualitative characterization}

From the three study sites, nine, seven, six and four ecotypes of beans, peanuts, soybeans and Bambara groundnuts respectively were inventoried (Figure 1). They were classified according to qualitative parameters such as color, seed shape, hylium's position and hylium's color (Table 5).

\section{Color of seed}

The color of seeds was the most diversified parameter compared to others. Some of these colors change from one leguminous crop to another but the color was mainly "white and red" which was observed in beans, peanuts and Bambara groundnuts. According to this color parameter, leguminous crops were classified into ecotypes. Seven ecotypes of peanuts were collected in all study sites with the maximum taken from Guinean Savannah highlands (five ecotypes, Figure 1). Nine ecotypes of beans were collected with the maximum of ecotypes taken from Western Highlands (West region; seven ecotypes) and the minimum taken from High Guinean Savannah (one ecotype). So, West region is the most diversified in terms of beans ecotypes compared to Northwest and Adamawa regions. Among the six ecotypes of Bambara groundnuts collected, five ecotypes were cultivated in Western Highlands (Northwest region). Four ecotypes of soybeans were collected and most of the ecotypes were collected from Guinean Savannah highlands. 


\section{Hylium color and position}

The hylium of leguminous crops were either peripheric or central while their color changes with the type of leguminous crops and their variety. Soybeans and Bambara groundnuts were crops with the most diversified hylium color.

\section{The form of seed}

The form of seed was either oval or spherical but it was mostly diversified for Bambara groundnuts. Peanuts and Bambara groundnuts which have the peripheric position of hylium have either oval (peanuts) or diversified shape (Bambara groundnuts). It may probably imply that the hylium position of seed may define the form of seed.

\section{Productivity of leguminous crops}

The productivity of leguminous crops in study sites show that the most cultivated beans ecotype was RLS (red long seed: $3130 \mathrm{Kg} \mathrm{ha}^{-1}$ ) (Figure 2). The less cultivated ecotypes were SB (stripped brown: $12 \mathrm{Kg} \mathrm{ha}^{-1}$ ) both found in Western Highlands (Mezam and Menchum respectively).

The most cultivated ecotype of peanuts was SR (stripped red: $5203 \mathrm{Kg}$ ha $^{-1}$ ) taken from High Guinean Savannah (Faro et Deo) and the less cultivated ecotype was $\mathrm{W}$ (white: $40 \mathrm{Kg} \mathrm{ha}^{-1}$ ) and $\mathrm{R}$ (red: $40 \mathrm{Kg} \mathrm{ha}^{-1}$ ) both taken from Western Highlands (Menoua).

The most produced ecotypes of Bambara groundnuts were $\mathrm{CB}$ (clear brown: $3576 \mathrm{Kg} \mathrm{ha}^{-1}$ ) from Guinean Savannah highlands (Vina) while the less produced was SY (stripped yellowish: $122 \mathrm{Kg} \mathrm{ha}^{-1}$ ), DB (dark brown: $122 \mathrm{Kg}$ $\mathrm{ha}^{-1}$ ) and $\mathrm{R}$ (red: $122 \mathrm{Kg} \mathrm{ha}{ }^{-1}$ ) all collected from Western Highlands (Menchum).

The most produced ecotypes of soybeans were YSS (yellowish small seed: $1715 \mathrm{Kg} \mathrm{ha}^{-1}$ ) taken from Western Highlands (Mifi) and the less produced ecotypes was YMS (yellowish medium seed: $18 \mathrm{Kg} \mathrm{ha}^{-1}$ ) taken from Guinean Savannah highlands (Faro et Deo).

\section{Quantitative characterization of leguminous crops}

Beans, peanuts and soybeans LBA, LSA, LBA/LSA and W50 parameters were all significantly different regarding among ecotypes ( $\mathrm{p}<$ 0.05) except W50 of soybeans (Table 6). Soybeans W50 was not significantly different $(\mathrm{p}=0.27)$ while Bambara groundnuts W50 was significantly different $(\mathrm{p}<0.05)$.

\section{PCA analysis of leguminous crops}

Beans ecotypes were gathered into three groups (Figure 3A): Groups $\mathrm{A}$ and $\mathrm{C}$ representing essentially leguminous from West region gathered 
according to LBA/LSA ratio for group A and W50 for group C. Group B mostly contains beans from Northwest and grouped according to LBA and LSA parameter. Peanuts ecotypes represented four groups (Figure 3B): Group A was essentially constituted by peanuts taken from Adamawa region and all gathered according to the higher values of LSA and W50. Group B represents ecotypes mostly collected from Adamawa and West and discriminated themselves with LBA and LBA/LSA ratio. Group C and D represents leguminous taken from all study sites and differentiate themselves with lower values of LBA and LBA/LSA ratio for group C and LSA and W50 for group D. Bambara groundnuts ecotypes represented three groups: Group A represented leguminous taken essentially from Northwest sites and which distinguished themselves with LSA parameter. Group B was only constituted by ecotypes taken from West sites and differentiate from others with W50 and LBA. Group C was mostly constituted by ecotypes from Adamawa which discriminate themselves from others ecotypes with LBA/LSA. Soybeans ecotypes presented two groups: Group A represented all ecotypes taken from West sites and were clustered according to LBA/LSA. Group B represents all ecotypes taken from Adamawa and were gathered according to LBA, LSA and W50.

\section{Discussion}

\section{Leguminous crops cultivation in study sites}

In Western and Guinean savannah highlands, farmers were really experienced in crops cultivations as agriculture is the main occupation of rural area inhabitants (Table 2). They often have at least 20 years of cultivation experience due to the ancestral inheritance practices taken from their family over the years. Among these farmers, cultivation of crops belongs mainly to the womenfolk as agriculture is often their daily routine work and they are considered as assistants to men who represent the head of the household and business of the family (JICA, 2015). That's why crops like soybeans which were mainly cultivated for trading was cultivated by men in Guinean Savannah highlands (Table 1). However, cultivating leguminous crops in these two areas (mention the areas) required some traditional knowledge to ensure good yield and productivity. Among these traditional knowledge, the keeping of seed was usually done by farmers with the aim of preserving the variety of their seeds (Table 3). These seeds were less susceptible to pest's attacks at field level and during conservation. Moreover, with years of practices, farmers found out that these varieties are tastier compared to others and do not need fertilizers for their production. ECAM 3, (2008) stated that farmers who often use improved seeds, were those using fertilizers for their production. Furthermore, saving seeds doesn't only help to improve agricultural biodiversity, but helps farmers and researchers to find varieties of 
crops that grow better in different regions, especially as the impacts of climate change becomes evident (Nierenberg, 2013). Finally, with disappearing of crop varieties over the last decades (Pautasso et al., 2012), saving seeds (seed preservation) is also contributing to genetic conservation of seed (Peres, 2016). Most of these farmers, who handled familiar farms, were poor and were not able to afford fertilizers (Table 4). 87.40\% of farmers in Cameroon are from rural area among them, $90.70 \%$ are poor and $97.80 \%$ self-finance their agricultural activity (ECAM 3, 2008). Abia et al. (2016) posited that approximately $80 \%$ of the population is engaged in agricultural systems with small farm sizes, almost 0.5 to 2 hectares per family subsequently the domination of low use of fertilizers.

\section{Characterization of leguminous crops}

Qualitative description of leguminous crops ecotypes suggested that these ecotypes were more relevant for farmers in terms of taste, productivity, adaptation to climate conditions and soil types. However, each of these ecotypes were more cultivated in some sites compared to others due to their capacity to fulfill the above-mentioned characteristics. That is why several ecotypes of beans for instance were found in western highlands compared to Guinean savannah highlands where only red ecotype was cultivated (table 5). In general, in western highlands, crops like peanuts and beans were cultivated for both trading and personal consumptions purposes. That was why farmers tried to diversify ecotypes of these crops to offer more choice to consumers and satisfy their demands.

The production of many ecotypes of leguminous crops like beans has a traditional background as they are special meals in this area which are just cooked with specific ecotype of beans like black beans. Likewise, the ecotypes like white small seed (WSS) and white round seed (WRS) which were mostly cultivated at Menoua site (Figure 2) have the honorific meaning as offering these beans to someone was the sign of respect toward this person. The important productivity of beans and peanuts in Western Highlands were also explained by the population's lack of dairy products and meats. They consume a lot of these crops as protein supplements and to supply their alimentation in proteins.

The lower production of Bambara groundnuts and soybeans crops in Western highlands were still linked to traditional issues. Indeed, Bambara groundnuts crop was several years ago cultivated as main crops for proteins supply in the alimentation of population. But with introduction of peanuts which were easier to cultivate compared to Bambara groundnuts, most of the farmers dropped Bambara groundnut cultivation and adopted peanuts cultivation instead. Nowadays, Bambara groundnuts is mostly cultivated by old women of at least 60 years old as they are most linked to their childhood 
traditions and are considered to be most experienced in this crop cultivation. Years ago, soybeans were introduced in Western highlands but most of farmers did not know how to consume this crop. So, several books written by IRAD were explaining to farmers how soybeans can be used as food. But, these farmers were mostly illiterate and so were unable to read. This crop (Bambara groundnut) was just abandoned or instead used to feed animals.

In Guinean savannah highlands, because of high rate of breeding, the alimentary supply in proteins are not lacking. Farmers do not find it really needful to produce important quantity and ecotypes of crops like beans and peanuts. They rather produce important quantity of crops like soybeans and Bambara groundnuts for trading purposes. Most of the farmers in this area have contracts with agribusiness companies which are using soybeans and peanuts for instance as a raw materials for oil production.

Morphological diversity of leguminous crops observed throughout study sites were also observed at the level of biometrics parameters of ecotypes except for few crops (Table 6). The length and weight of seeds confirm that peanuts and beans were all significantly different according to study sites. The quality of soil, the climate, the temperature of the area and sunshine may have influenced phenotype and genotype of leguminous crops seeds. 


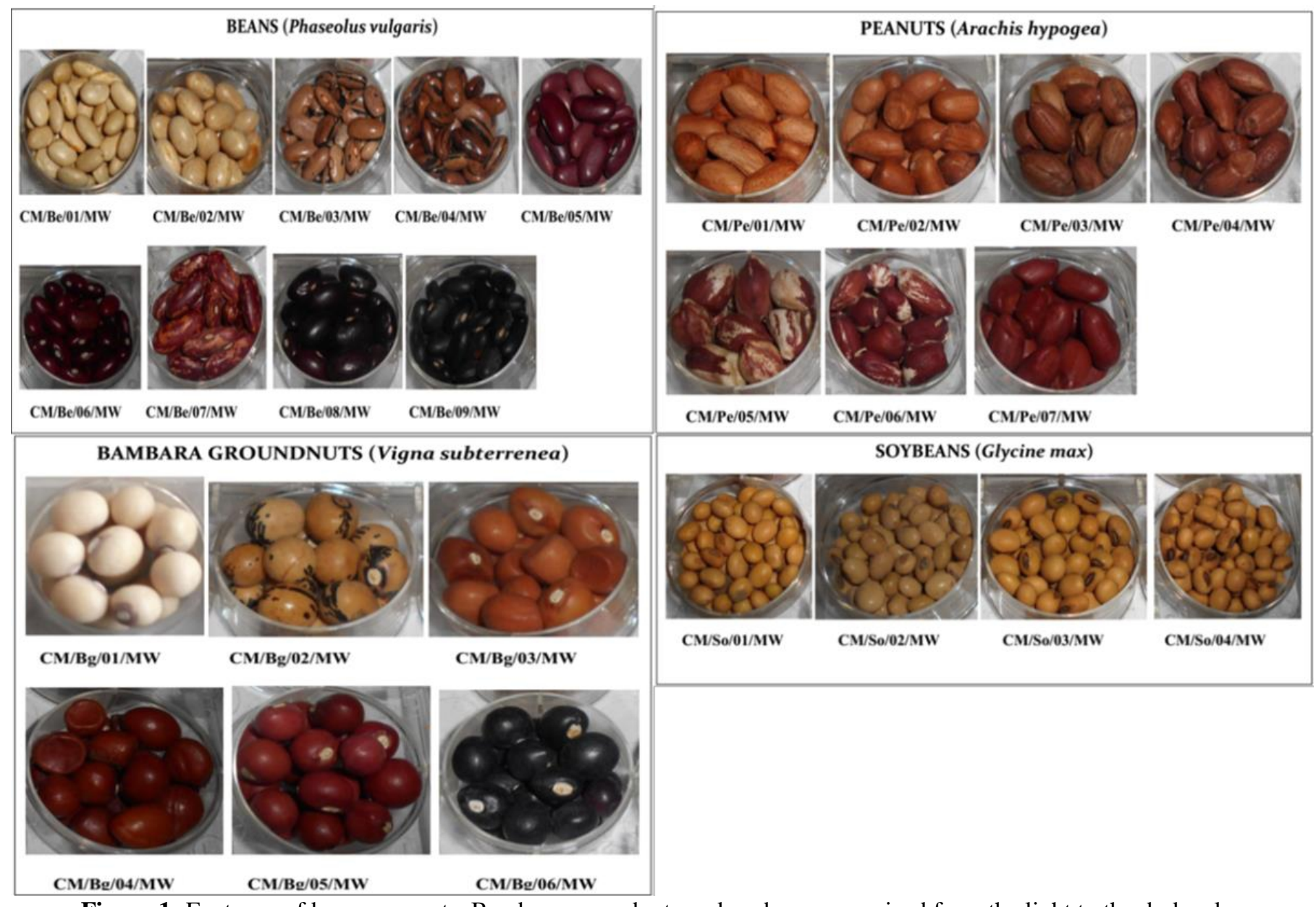

Figure 1: Ecotypes of beans, peanuts, Bambara groundnuts and soybeans organized from the light to the dark color 
Table 5: Morphological description of leguminous crops identified during investigation in three regions of Cameroon

\begin{tabular}{|c|c|c|c|c|c|c|c|}
\hline $\begin{array}{l}\text { Leguminous } \\
\text { crops }\end{array}$ & Ecotypes code & Colors & Form of seed & Hylium position & Hylium color & Regions & Divisions \\
\hline \multirow[t]{7}{*}{ Peanuts } & $\mathrm{CM} / \mathrm{Pe} / 01 / \mathrm{MW}$ & White (W) & Oval & Peripheric & Yellowish & Adamawa & Faro et Déo \\
\hline & $\mathrm{CM} / \mathrm{Pe} / 02 / \mathrm{MW}$ & Clear brown $(\mathrm{CB})$ & Oval & Peripheric & Yellowish & West, Northwest & Menoua, Mifi, Mezam, Menchum \\
\hline & $\mathrm{CM} / \mathrm{Pe} / 03 / \mathrm{MW}$ & Brown (B) & Oval & Peripheric & Yellowish & Adamawa, Northwest & Vina, Mezam, Menchum \\
\hline & $\mathrm{CM} / \mathrm{Pe} / 04 / \mathrm{MW}$ & Dark brown (DB) & Oval & Peripheric & Yellowish & West & Menoua, Mifi \\
\hline & $\mathrm{CM} / \mathrm{Pe} / 05 / \mathrm{MW}$ & Stripped brown (SB) & Oval & Peripheric & Yellowish & Adamawa & Vina \\
\hline & $\mathrm{CM} / \mathrm{Pe} / 06 / \mathrm{MW}$ & Stripped red (SR) & Oval & Peripheric & Yellowish & Adamawa & Faro et Déo \\
\hline & $\mathrm{CM} / \mathrm{Pe} / 07 / \mathrm{MW}$ & $\operatorname{Red}(\mathrm{R})$ & Oval & Peripheric & Yellowish & $\begin{array}{l}\text { Adamawa, West, } \\
\text { Northwest }\end{array}$ & $\begin{array}{l}\text { Faro et Déo, Menoua, Mifi, Mezam, } \\
\text { Menchum }\end{array}$ \\
\hline \multirow[t]{9}{*}{ Beans } & $\mathrm{CM} / \mathrm{Be} / 01 / \mathrm{MW}$ & White small seed (WSS) & Spherical & Central & White & West & Menoua, Mifi \\
\hline & $\mathrm{CM} / \mathrm{Be} / 02 / \mathrm{MW}$ & White round seed (WRS) & Spherical & Central & White & West & Menoua \\
\hline & $\mathrm{CM} / \mathrm{Be} / 03 / \mathrm{MW}$ & Stripped white (SW) & Spherical & Central & White & Northwest & Menchum \\
\hline & $\mathrm{CM} / \mathrm{Be} / 04 / \mathrm{MW}$ & Stripped brown (SB) & Spherical & Central & White & Northwest & Menchum \\
\hline & $\mathrm{CM} / \mathrm{Be} / 05 / \mathrm{MW}$ & Red long seed (RLS) & Spherical & Central & White & West & Menoua, Mifi \\
\hline & $\mathrm{CM} / \mathrm{Be} / 06 / \mathrm{MW}$ & $\operatorname{Red}(\mathrm{R})$ & Spherical & Central & White & $\begin{array}{l}\text { West, Northwest, } \\
\text { Adamawa }\end{array}$ & $\begin{array}{l}\text { Menoua, Mifi, Mezam, Menchum, } \\
\text { Vina, Faro et Déo }\end{array}$ \\
\hline & $\mathrm{CM} / \mathrm{Be} / 07 / \mathrm{MW}$ & Stripped (S) & Spherical & Central & White & West, Northwest & Menoua, Mifi, Mezam, Menchum \\
\hline & $\mathrm{CM} / \mathrm{Be} / 08 / \mathrm{MW}$ & Dark violet (DV) & Spherical & Central & White & West & Menoua \\
\hline & $\mathrm{CM} / \mathrm{Be} / 09 / \mathrm{MW}$ & Black (B) & Spherical & Central & White & West, Northwest & Menoua, Mifi, Mezam \\
\hline \multirow[t]{6}{*}{$\begin{array}{l}\text { Bambara } \\
\text { groundnuts }\end{array}$} & $\mathrm{CM} / \mathrm{Bg} / 01 / \mathrm{MW}$ & White (W) & Spherical & Peripheric & $\begin{array}{l}\text { White with brown } \\
\text { outline }\end{array}$ & Adamawa & Faro et Déo \\
\hline & $\mathrm{CM} / \mathrm{Bg} / 02 / \mathrm{MW}$ & Clear brown $(\mathrm{CB})$ & Flat and oval & Peripheric & White & $\begin{array}{l}\text { West, Northwest, } \\
\text { Adamawa }\end{array}$ & Menoua, Menchum, Vina \\
\hline & $\mathrm{CM} / \mathrm{Bg} / 03 / \mathrm{MW}$ & Stripped yellowish (SY) & Spherical & Peripheric & White & Northwest, Adamawa & Menchum, Faro et Déo \\
\hline & $\mathrm{CM} / \mathrm{Bg} / 04 / \mathrm{MW}$ & Dark brown (DB) & Flat and oval & Peripheric & White & West, Northwest & Mifi, Mezam, Menchum \\
\hline & $\mathrm{CM} / \mathrm{Bg} / 05 / \mathrm{MW}$ & $\operatorname{Red}(\mathrm{R})$ & Oval & Peripheric & White & Northwest & Menchum \\
\hline & $\mathrm{CM} / \mathrm{Bg} / 06 / \mathrm{MW}$ & Black purplish (BP) & Flat and spherical & Peripheric & White & Northwest & Menchum \\
\hline \multirow[t]{4}{*}{ Soybeans } & $\mathrm{CM} / \mathrm{So} / 01 / \mathrm{MW}$ & $\begin{array}{l}\text { Yellowish medium seed } \\
\text { (YMS) }\end{array}$ & Spherical & Central & Brown & Adamawa & Vina, Faro et Déo \\
\hline & $\mathrm{CM} / \mathrm{So} / 02 / \mathrm{MW}$ & Yellowish small seed (YSS) & Spherical & Central & Brown & $\begin{array}{l}\text { West, Adamawa, } \\
\text { Northwest }\end{array}$ & $\begin{array}{l}\text { Mifi, Faro et Déo, Mezam, } \\
\text { Menchum }\end{array}$ \\
\hline & $\mathrm{CM} / \mathrm{So} / 03 / \mathrm{MW}$ & Yellowish big seed (YBS) & Spherical & Central & $\begin{array}{l}\text { Yellowish with brown } \\
\text { outline }\end{array}$ & Adamawa, Northwest & Faro et Déo, Mezam, Menchum \\
\hline & $\mathrm{CM} / \mathrm{So} / 04 / \mathrm{MW}$ & Dark yellowish (DY) & Spherical & Central & Brown & West & Menoua \\
\hline
\end{tabular}



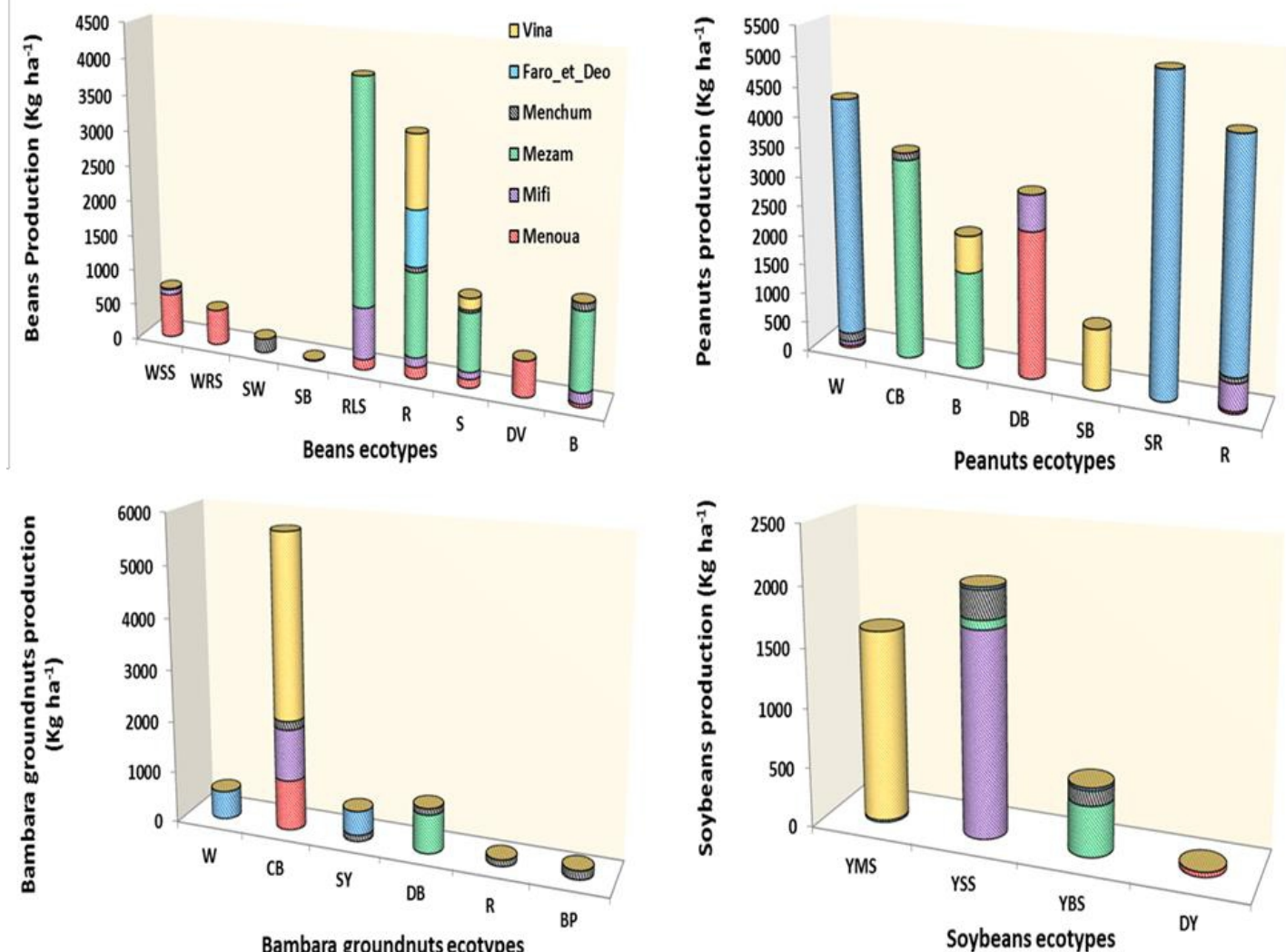

Figure 2: Productivity of leguminous crops distributed according to each ecotypes and per sites. Beans (WSS: white small seed; WRS: white round seed; SW: stripped white; SB: stripped brown; RLS: red long seed; R: red; S: stripped; DV: dark violet; B: black); Peanuts (W: white; CB: clear brown; B: brown; DB: dark brown; SB: stripped brown; SR: stripped red; R: red); Bambara groundnuts (W: white; CB: clear brown; SY: stripped yellowish; DB: dark brown; R: red; BP: black purplish); Soybeans (YMS: yellow red seed; YSS: yellow small seed; YBS: yellow big seed; DY: dark yellowish) 

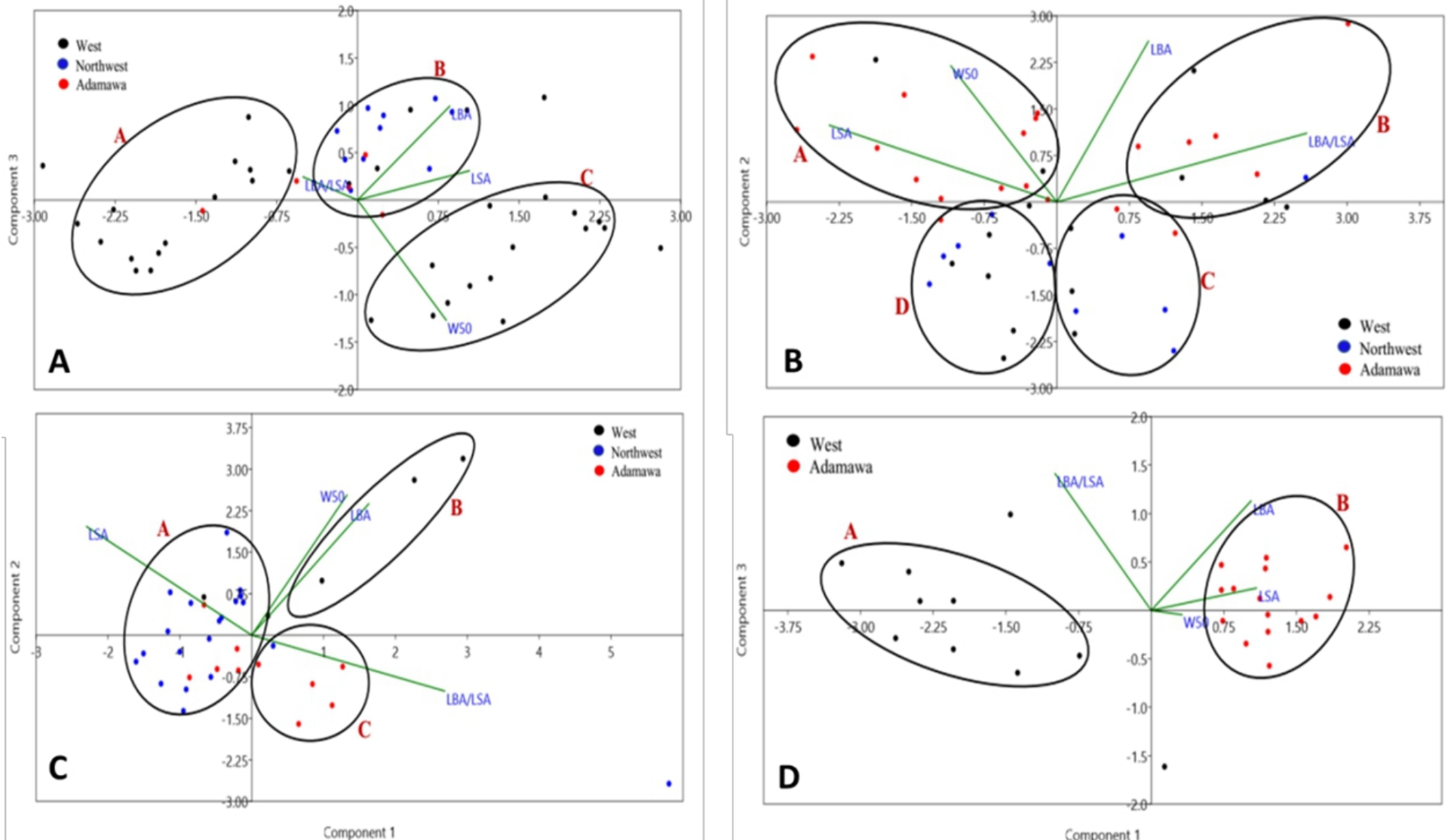

Figure 3: PCA analysis of leguminous crops ecotypes according to biometric parameters LSA (lenght of small axis), LBA (length of big axis),

LBA/LSA (ratio between the two parameters) and W50 (weigh of 50 seeds). A: PCA of beans; B: PCA of peanuts; C: PCA of Bambara groundnuts; D: PCA of soybeans 
Table 6: Biometric parameters of leguminous crops by ecotypes; Means were separated with Unequal N HSD test (Letters on each values) and P value was calculated with one way ANOVA (*significant difference)

\begin{tabular}{|c|c|c|c|c|c|c|c|c|c|}
\hline \multirow[t]{2}{*}{ Ecotypes } & \multicolumn{4}{|c|}{ Beans } & \multirow[t]{2}{*}{ Ecotypes } & \multicolumn{4}{|c|}{ Peanuts } \\
\hline & LBA & LSA & LBA/LSA & W50 & & LBA & LSA & LBA/LSA & W50 \\
\hline CM/Be/01/MW & $8.15 \pm 0.11^{\mathrm{c}}$ & $3.53 \pm 0.45^{\mathrm{ac}}$ & $2.71 \pm 0.21^{\mathrm{ab}}$ & $10 \pm 0^{\mathrm{a}}$ & CM/Pe/01/MW & $14.13 \pm 0.14^{\mathrm{ab}}$ & $6.42 \pm 0.06^{\mathrm{a}}$ & $2.20 \pm 0.05^{\mathrm{b}}$ & $20 \pm 0^{b c}$ \\
\hline $\mathrm{CM} / \mathrm{Be} / 02 / \mathrm{MW}$ & $11.26 \pm 0.01^{\mathrm{ab}}$ & $6.05 \pm 0.16^{\mathrm{b}}$ & $1.89 \pm 0.10^{\mathrm{a}}$ & $23.75 \pm .22^{\mathrm{de}}$ & $\mathrm{CM} / \mathrm{Pe} / 02 / \mathrm{MW}$ & $11.38 \pm 0.10^{\mathrm{c}}$ & $6.89 \pm 0.03^{\mathrm{abc}}$ & $1.65 \pm 0.03^{\mathrm{a}}$ & $16.87 \pm 0.25^{\mathrm{b}}$ \\
\hline CM/Be/03/MW & $11.93 \pm 0.03^{\mathrm{ab}}$ & $4.78 \pm 0.03^{\mathrm{abc}}$ & $2.49 \pm 0.01^{\mathrm{ab}}$ & $11.66 \pm 0.19^{\mathrm{ab}}$ & $\mathrm{CM} / \mathrm{Pe} / \mathbf{0 3} / \mathrm{MW}$ & $15.11 \pm 0.03^{\mathrm{b}}$ & $7.41 \pm 0.11^{\mathrm{abc}}$ & $2.05 \pm 0.05^{\mathrm{ab}}$ & $25 \pm 0^{\mathrm{ad}}$ \\
\hline $\mathrm{CM} / \mathrm{Be} / 04 / \mathrm{MW}$ & $12.14 \pm 0.10^{\mathrm{ab}}$ & $4.96 \pm 0.08^{\mathrm{ab}}$ & $2.48 \pm 0.08^{\mathrm{ab}}$ & $10 \pm 0^{\mathrm{a}}$ & $\mathrm{CM} / \mathrm{Pe} / 04 / \mathrm{MW}$ & $14.67 \pm 0.17^{\mathrm{ab}}$ & $6.67 \pm 0.14^{\mathrm{ab}}$ & $2.21 \pm 0.06^{\mathrm{b}}$ & $25 \pm 0^{\mathrm{a}}$ \\
\hline $\mathrm{CM} / \mathrm{Be} / 05 / \mathrm{MW}$ & $13.21 \pm 0.14^{\mathrm{b}}$ & $4.57 \pm 0.12^{\mathrm{abc}}$ & $2.96 \pm 0.15^{\mathrm{ab}}$ & $20 \pm 0^{c}$ & $\mathrm{CM} / \mathrm{Pe} / 05 / \mathrm{MW}$ & $13.78 \pm 0.11^{\mathrm{ab}}$ & $8.71 \pm 0.10^{\mathrm{c}}$ & $1.58 \pm 0.03^{\mathrm{a}}$ & $33.12 \pm 0.18^{\mathrm{e}}$ \\
\hline $\mathrm{CM} / \mathrm{Be} / 06 / \mathrm{MW}$ & $10.75 \pm 0.01^{\mathrm{a}}$ & $5.03 \pm 0.09^{\mathrm{ab}}$ & $2 \pm 0.04^{\mathrm{ab}}$ & $13.75 \pm 0.29^{\mathrm{b}}$ & $\mathrm{CM} / \mathrm{Pe} / 06 / \mathrm{MW}$ & $13.78 \pm 0.02^{\mathrm{ab}}$ & $8.01 \pm 0.08^{b c}$ & $1.72 \pm 0.04^{\mathrm{a}}$ & $25 \pm 0^{\mathrm{a}}$ \\
\hline CM/Be/07/MW & $13.80 \pm 0.19^{\mathrm{b}}$ & $3.97 \pm 0.08^{\mathrm{abc}}$ & $3.48 \pm 0.11^{\mathrm{ab}}$ & $25.81 \pm 0.13^{\mathrm{e}}$ & CM/Pe/07/MW & $12.41 \pm 0.08^{\mathrm{ac}}$ & $7.23 \pm 0.08^{\mathrm{abc}}$ & $1.72 \pm 0.06^{\mathrm{a}}$ & $21.25 \pm 0.23^{\mathrm{cd}}$ \\
\hline CM/Be/08/MW & $10.64 \pm 0.03^{\mathrm{a}}$ & $4.26 \pm 0.25^{\mathrm{abc}}$ & $2.70 \pm 0.26^{\mathrm{ab}}$ & $21.25 \pm 0.13^{\mathrm{cd}}$ & $P$ value & $0.00 *$ & $0.00 *$ & $0.00^{*}$ & $0.00 *$ \\
\hline CM/Be/09/MW & $7.61 \pm 0.18^{\mathrm{c}}$ & $2.23 \pm 0.12^{\mathrm{c}}$ & $3.49 \pm 0.15^{\mathrm{b}}$ & $10 \pm 0^{\mathrm{a}}$ & & & & & \\
\hline$P$ value & $0.00 *$ & $\mathbf{0 . 0 0 *}$ & $0.00 *$ & $0.00 *$ & & & & & \\
\hline
\end{tabular}

\begin{tabular}{|c|c|c|c|c|c|c|c|c|c|}
\hline \multirow[t]{2}{*}{ Ecotypes } & \multicolumn{4}{|c|}{ Bambara groundnuts } & \multirow[t]{2}{*}{ Ecotypes } & \multicolumn{4}{|c|}{ Soybeans } \\
\hline & LBA & LSA & LBA/LSA & W50 & & $\overline{\text { LBA }}$ & LSA & LBA/LSA & W50 \\
\hline $\mathrm{CM} / \mathrm{Bg} / \mathbf{0 1} / \mathrm{MW}$ & $12.24 \pm 0.07^{\mathrm{a}}$ & $9.85 \pm 0.09^{\mathrm{a}}$ & $1.24 \pm 0.02^{\mathrm{a}}$ & $35 \pm 0^{\mathrm{b}}$ & CM/So/01/MW & $6.86 \pm 0.03^{\mathrm{b}}$ & $4.49 \pm 0.01^{\mathrm{c}}$ & $1.52 \pm 0.01^{\mathrm{ab}}$ & $5 \pm 0^{\mathrm{a}}$ \\
\hline $\mathrm{CM} / \mathrm{Bg} / \mathbf{0 2} / \mathrm{MW}$ & $11.44 \pm 0.05^{\mathrm{a}}$ & $9.24 \pm 0.01^{\mathrm{a}}$ & $1.23 \pm 0.02^{\mathrm{a}}$ & $30 \pm 0^{\mathrm{a}}$ & CM/So/02/MW & $3.88 \pm 0.08^{\mathrm{a}}$ & $1.87 \pm 0.06^{\mathrm{a}}$ & $2.06 \pm 0.03^{\mathrm{c}}$ & $5 \pm 0^{\mathrm{a}}$ \\
\hline $\mathrm{CM} / \mathrm{Bg} / \mathbf{0 3} / \mathrm{MW}$ & $12.05 \pm 0.14^{\mathrm{a}}$ & $9.79 \pm 0.12^{\mathrm{a}}$ & $1.23 \pm 0.02^{\mathrm{a}}$ & $30.62 \pm 0.09^{\mathrm{a}}$ & CM/So/03/MW & $4.55 \pm 0.08^{\mathrm{a}}$ & $2.71 \pm 0.08^{\mathrm{b}}$ & $1.67 \pm 0.01^{\mathrm{b}}$ & $4.16 \pm 0.33^{\mathrm{a}}$ \\
\hline $\mathrm{CM} / \mathrm{Bg} / \mathbf{0 4} / \mathrm{MW}$ & $11.39 \pm 0.14^{\mathrm{a}}$ & $9.39 \pm 0.11^{\mathrm{a}}$ & $1.20 \pm 0.02^{\mathrm{a}}$ & $31 \pm 0.16^{\mathrm{a}}$ & CM/So/04/MW & $7.33 \pm 0.02^{\mathrm{b}}$ & $5.13 \pm 0.05^{\mathrm{d}}$ & $1.43 \pm 0.03^{\mathrm{a}}$ & $5 \pm 0^{\mathrm{a}}$ \\
\hline $\mathrm{CM} / \mathrm{Bg} / \mathbf{0 5} / \mathrm{MW}$ & $10.71 \pm 0.18^{\mathrm{a}}$ & $9.53 \pm 0.02^{\mathrm{a}}$ & $1.12 \pm 0.06^{\mathrm{a}}$ & $65 \pm 0^{c}$ & $P$ value & $0.00 *$ & $0.00 *$ & $0.00 *$ & 0.27 \\
\hline $\mathrm{CM} / \mathrm{Bg} / \mathbf{0 6} / \mathrm{MW}$ & $11.39 \pm 0.14^{\mathrm{a}}$ & $9.42 \pm 0.11^{\mathrm{a}}$ & $1.20 \pm 0.02^{\mathrm{a}}$ & $30 \pm 0^{\mathrm{a}}$ & & & & & \\
\hline$P$ value & 0.45 & 0.84 & 0.40 & $0.00 *$ & & & & & \\
\hline
\end{tabular}




\section{Conclusion}

One of the key factors of food security in Cameroon is the diversification of cultures such as cultivation of leguminous crops. They take an important place in alimentation of poor populations and improving of livelihood of the poor resource farmers. Subsequently, most of the farmers who were mainly woman kept their seed for next cultivation season and were unable to afford fertilizers. Most of these farmers have mastery of cultivation methods of these crops with at least 10 years of experience for peanuts, beans and Bambara groundnuts. Moreover, a qualitative diversity of these leguminous crops was found throughout study sites and quantitative analysis confirms this diversity for beans, peanuts and soybeans. It will be interesting to constitute a seed bank with all these ecotypes to keep these diversity of leguminous crops encountered in agro ecological zones of Cameroon for sustainable production in the face of changing climate.

\section{Acknowledgement}

We wish to express our gratitude to Assistance Program of Doctoral student (PAD) which granted the first author financial support during fieldwork. We would like to thank the Laboratory staff of Biodiversity and Sustainable Development of the University of Ngaoundere which hosted this research. Many thanks go to Chukwuebuka Christopher OKOLO from Mekelle University, Ethiopia for proofreading and English editing.

\section{References:}

1. Abia, W.A., Shum, C.E., Fomboh, R., Ntungwe, E.N. and Ageh, M.T. (2016). Agriculture in Cameroon: Proposed Strategies to Sustain Productivity: International Journal for Research in Agricultural Research, 2, p. 13.

2. AGRIDAPE (2016). Revaloriser les espèces agricoles traditionnelles sous-utilisées: 32, p. 1-31.

3. Akibode, C.S.(2011). Trends in the prouction, trade and consumption of food-legume crops in sub-saharan Africa: Michigan State University, $85 \mathrm{p}$.

4. Binam, J.N., Tonyè, J., Wandji, N., Nyambi, G. and Akoa, M. (2004). Factors affecting the technical efficiency among smallholder farmers in the slash and burn agriculture zone of Cameroon: Food Policy, 29, p. 531-545, doi: 10.1016/j.foodpol.2004.07.013.

5. BMEL (2015). Understanding global food security and nutrition: Federal Ministry of Food and Agriculture, , p. 1-32.

6. Bossuet, J. and Vadez, V. (2013). S'appuyer sur les multiples bén éfices graines des legumineuses a pour une agriculture plus productive et nutritive dans les tropiques semi-arides: Sécheresse, 24, p. 314-321. 
7. Dobermann, A. and Nelson, R. (2013). Opportunities and Solutions for Sustainable Food Production. High-Level Panel of Eminent Persons on the Post-2015 Development Agenda: Irri,, p. 25, doi: 10.1037/00223514.90.4.644.

8. DSCN (2002). Conditions de vie des populations et profil de pauvreté au Cameroun en 2001: premiers résultats.:

9. ECAM 3 (2008). Profil De Pauvrete Au Cameroun En 2007. p.157

10. FAO (2016). Soils and pulses symbiosis for life:

11. Graham, P.H. and Vance, C.P. (2003). Update on Legume Utilization Legumes: Importance and Constraints to Greater Use: Plant Physiology, 131, p. 872-877, doi:10.1104/pp.017004.872.

12. Ibeawuchi, I.I. (2007). Landrace leguminous: Synopsis of the Culture, importance, potentials and roles in agricultural production systems: Journal of Biological Sciences, 7, p. 464-474.

13. INS (2015). Rapport national sur les objctifs du millénaire pour le developpement en 2015.:

14. IRAD (2013). Contribution de la recherche a l'amelioration de la production et la consommation des legumineuses alimentaires au Cameroon:

15. IRAD (2008). Rapport National Sur L ' État Des Ressources Phytogénétiques Pour L'alimentation et 1' agriculture:

16. Jayne, T.S., Anriquez, G. and Collier, E. (2013). African agriculture toward 2030: changes in urbanization and agricultural land dynamics and their implications for CGIAR: Iindependent Science and Partnership Council. p. 62

17. JICA (2015). 2015 Country Report of Gender Profile (Cameroon). p.38.

18. Kouebou, C.P., Achu, M., Nzali, S., Chelea, M., Bonglaisin, J., Kamda, A., Djiele, P., Yadang, G., Ponka, R., Ngoh Newilah, G., Nkouam, G., Teugwa, C. and Kana Sop, M.M. (2013). A review of composition studies of Cameroon traditional dishes: Macronutrients and minerals: Food Chemistry, 140, p. 483-494, doi: 10.1016/j.foodchem.2013.01.003.

19. Madzivhandila, T., Sibanda, S., Yamdjeu, W.A., Moalosi, K. and Gwelo, F.A. (2016). Achieving Food Security and Nutrition. In: Africa Agriculture Status Report 2016 p. 300.

20. Maingi, J.M., Shisanya, C.A., Gitonga, N.M. and Hornetz, B. (2001). Nitrogen fixation by common bean (Phaseolus vulgaris L .) in pure and mixed stands in semi-arid south-east Kenya: European Journal of Agronomy, 14, p. 1-12.

21. Meena, V.S., Maurya, B.R. and Verma, J.P. (2014). Does a rhizospheric microorganism enhance $\mathrm{K}^{+}$availability in agricultural 
soils? Microbiological Research, 169, p. 337-347, doi: 10.1016/j.micres.2013.09.003.

22. MINADER (2012). Annuaire des Statistiques du Secteur Agricole. Campagnes 2009 \& 2010.:

23. MINRESI (2007). Deuxième rapport sur l'état des ressources phytogénétiques pour l'alimentation et l'agriculture au Cameroun, $\mathrm{p}$. 60 .

24. Molua, E. (2008). Turning up the heat on African agriculture: The impact of climate change on Cameroon's agriculture: African Journal of Agricultural and Resource, 2, p. 45-64, doi: 10.1016/j.jmmm.2008.02.107.

25. Molua, E.L. and Lambi, C.M. (2015). Climate Hydrology and Water Resources in Cameroon.:

26. Morel, M.A., Braña, V. and Castro-sowinski, S. (2012). Legume Crops , Importance and Use of Bacterial Inoculation to Increase Production. In: Crop Plant (Goyal, A., ed.) InTech Published, p. 217-240.

27. Nierenberg, D. (2013). The Case for Seed Saving | HuffPost:

28. Pautasso, M., Aistara, G., Barnaud, A., Caillon, S., Clouvel, P., Delêtre, M., Demeulenaere, E., Santis, P., Doring, T., Eloy, L., Emperaire, L., Garine, E., Goldringer, I., Jarvis, D., Joly, H., Leclerc, C., Louafi, S., Martin, P., Massol, F., McGuire, S., McKey, D., Padoch, C., Soler, C., Thomas, M. and Tramontini, S. (2012). Seed exchange networks for agrobiodiversity conservation. A review: Agronomy for Sustainable Development, 33, p. 151-175, doi: 10.1007/s13593-012-0089-6.

29. Peres, S. (2016). Saving the gene pool for the future: Seed banks as archives: Studies in History and Philosophy of Biological and Biomedical Sciences, 55, p. 96-104, doi: 10.1016/j.shpsc.2015.09.002.

30. Sinclair, T.R. and Vadez, V. (2012). The future of grain legumes in cropping systems: Crop \& Pasture Science, 63, p. 501-512.

31. Touré, Y., Koné, M., Silué, S. and Kouadio, Y.J. (2013). Prospection, collecte et caracterisation agromorphologique des morphotypes de voandzou (Vigna subterranea L. Verdc. Fabacea) de la zone savanicole en Côte d'ivoire: European Scientific Journal, 9, p. 308-325. 